pag

Business School

WORKING PAPER SERIES

Working Paper 2014-057

\section{The Role of Natural Gas Consumption} and Trade in Tunisia's Output

Mohamed Arouri

Sahbi Farhani

Muhammad Shahbaz

Frédéric Teulon

http://www.ipag.fr/fr/accueil/la-recherche/publications-WP.html

IPAG Business School

184, Boulevard Saint-Germain

75006 Paris

France 


\title{
The Role of Natural Gas Consumption and Trade in Tunisia's Output
}

\author{
Mohamed Arouri \\ EDHEC Business School, France \\ E-Mail: Mohamed.arouri@u-clermont1.fr
}

Sahbi Farhani

University of Monastir, Tunisia

Email: $\underline{\text { sahbi_1984@yahoo.fr }}$

Muhammad Shahbaz

COMSATS Institute of Information Technology, Lahore Campus, Pakistan.

Email: shahbazmohd@live.com

Frédéric Teulon

IPAG Business School, IPAG - Lab, France

E-Mail:f.teulon@ipag.fr

\begin{abstract}
This paper examines the impact of natural gas consumption, real gross fixed capital formation and trade on the real GDP in the case of Tunisia over the period 1980-2010. We use an Autoregressive Distributed Lag (ARDL) bounds testing approach to test the existence of a longterm relationship between the variables. The Vector Error Correction Method (VECM) Granger approach is applied to test the direction of the causal relation between the series. Our findings indicate the existence of a long-term relationship among the variables. Natural gas consumption, real gross fixed capital formation and trade add in economic growth. Natural gas consumption, real gross fixed capital formation and real trade Granger-cause real GDP. These findings open up new insights for policymakers to formulate a comprehensive energy policy to sustain economic growth in the long term.
\end{abstract}

Keywords: Natural gas consumption, Economic growth, ARDL approach 


\section{Introduction}

Natural gas, as a vital non-renewable energy source, plays an increasingly important role in stimulating economic activity in developed and developing economies across the globe (Shahbaz et al., 2013). As the oil reserves in many monopolies of the world are being depleted, the availability of a viable alternative such as natural gas is becoming increasingly important. Tunisia is a net importer of hydrocarbon products. Domestic crude production is 91,380 barrels per day, but refining capacity is only 34,000 barrels a day. Proven reserves are approximately 400 million barrels. Tunisia has one oil refinery on the north coast in Bizerte and in May 2006 awarded a tender to Qatar Petroleum for a second at La Skhira, near Gabes. Natural gas production is currently approximately equivalent to 3 million tons of oil per annum. Proven reserves are about 65.13 billion cubic feet, two-thirds of which are located offshore. ${ }^{1}$ In this case, use of natural gas in Tunisia is growing as it is increasingly seen as a good alternative to oil. In addition, natural gas may mitigate $\mathrm{CO}_{2}$ emissions relative to other fossil fuels. In light of the commitments to reduce $\mathrm{CO}_{2}$ dioxide emissions through the Kyoto protocol and other countryspecific initiatives, governments encourage the use of natural gas over other fossil fuels as well as the viability of renewable energy sources. Indeed, the recent interest in the use of natural gas in the energy policy discussions on reducing emissions poses the question of the role of natural gas consumption in the economic growth process (Apergis and Payne, 2010).

Tunisia signed with the United States (US) a Trade and Investment Framework Agreement (TIFA) in October 2002 and follow-up TIFA Council meetings were held in October 2003, June 2005, and March 2008. In 2004, Tunisia signed the Agadir Agreement, a framework agreement

\footnotetext{
${ }^{1}$ Source: http://globaledge.msu.edu/countries/tunisia/economy
} 
for a multilateral trade treaty with Egypt, Jordan, and Morocco. The Agadir Agreement creates a potential market of over 100 million people across North Africa and into the Middle East. The government still retains control over certain "strategic" sectors of the economy (finance, hydrocarbons, aviation, electricity and gas distribution, and water resources) but the private sector is playing an increasingly important role. Tunisia is a founding member of the World Trade Organization (WTO) and is publicly committed to a free trade regime and export-led growth. In August 2010, the Government of Tunisia passed a law opening the Tunisian economy to foreign franchises in the sectors of retail/distribution, tourism, automotives, and training. Tunisia must approve franchising in other sectors, such as food service and real estate, on a caseby-case basis.

Empirically, there is a clear lack of consensus among the researchers over the relationship between natural gas consumption and economic growth, although the number of papers is limited in the literature. The main reason for the lack of consensus is that most of these studies have been conducted in a bivariate framework to test Granger causality. This result, with biased and inconsistent estimates, is due to the omitted relevant variables that affect economic growth and natural gas consumption. Therefore, inclusion of some other variables in a multivariate framework will provide better and more reliable results for analysing the relationship between economic growth and natural gas consumption. That is why some recent studies on Granger causality have started to examine this relationship between economic growth and natural gas consumption, including relevant variables such as capital, labour or exports (Apergis and Payne, 2010; Kum et al., 2012; Shahbaz et al., 2013). In addition, according to Lütkepohl (1982), 
omission of relevant variables makes the estimates biased and inconsistent. This means that a bivariate system can yield no causality from neglected variables.

This study contributes to the literature by examining the causal relationship between natural gas consumption and economic growth for Tunisia. Specifically, it contributes to existing energy literature in three ways. First, until now, no one has emphasized the importance of this subject for the Tunisian case. Second, the analysis will be undertaken within a production model framework by including measures for capital measures by gross fixed capital formation and trade. Third, following the studies by Moroney (1990), Lee (2005), Narayan and Smyth (2008), Apergis and Payne (2010), Işik (2010), Kum et al. (2012), Lim and Yoo (2012) and Shahbaz et al. (2013), the sign and magnitude of the respective coefficients will be discussed in relation to the various hypotheses on the natural gas consumption-growth nexus.

The remainder of this paper is organized as follows: Section 2 carries out a literature review; Section 3 highlights data and methodology; Section 4 presents empirical results; and the final section concludes the paper with policy implications.

\section{Natural gas consumption-growth literature}

The study of the relationship between natural gas consumption and economic growth can be categorized into four types. The first type only considered bivariate model for said nexus (Işik, 2010; Lim and Yoo, 2012). The second type examined the causal relationship between natural gas consumption and economic growth including capital or capital and labor (Apergis and Payne, 2010; Kum et al., 2012). The third type included trade indicator (Shahbaz et al., 2013). Finally, the fourth type used natural gas with others several disaggregate categories of energy as coal, oil, electricity, etc. (Yu and Choi, 1985; Yang, 2000; Aqeel and Butt, 2001; Fatai et al., 2004; Lee 
and Chang, 2005; Zamani, 2007; Asghar, 2008; Hu and Lin, 2008; Reynolds and Kolodziej, 2008; Sari et al., 2008; Khan and Ahmed, 2009; Ighodaro, 2010; Payne, 2011).

Starting with the first type, Işik (2010) examined the role of natural gas consumption in economic growth of Turkey by using ARDL model over the period of 1977-2008. He found a positive impact of natural gas consumption on economic growth in short run but in long run, it is positive. Lim and Yoo (2012) investigated the causality issue between natural gas consumption and economic growth in Korea over the period of 1991-2008. They exposed that the feedback effect exists between natural gas consumption and economic growth.

In the second type, Apergis and Payne (2010) probed the relationship between real GDP, natural gas consumption, real gross fixed capital formation, and labor force for a panel of 67 countries within a multivariate framework over the period of 1992-2005. Using Pedroni's $(1999,2004)$ heterogeneous panel cointegration test, they found a long-run equilibrium relationship between these variables. Moreover, they noted that the bidirectional causality between natural gas consumption and economic growth in is found. In the same way, Kum et al. (2012) examined the relationship between natural gas consumption, economic growth and capital for G-7 countries over the period of 1970-2008. They provided mixed results by using a bootstrap-corrected causality test. For Italy, the Granger causality is from natural gas consumption to growth and United Kingdom adverse. For pattern of France, Germany and United States, there is bidirectional Granger causality between natural gas and growth.

In the third type, Shahbaz et al. (2013) emphasized the importance of the exports, as a trade factor, in the relationship between real GDP, natural gas consumption, real capital, and labor in Pakistan over the period of 1972-2010. They noted that natural gas consumption, capital, labor 
and exports add in economic growth. The causality results reported that natural gas consumption causes economic growth.

In the last type, Yu and Choi (1985) used Sims and Granger-causality tests and found the unidirectional causality from natural gas consumption to real GNP for the UK, but the absence of a causal relationship between natural gas consumption and real GDP for the US and Poland over the period 1947-1979. In case of Taiwan, Yang (2000) revealed the absence of cointegrated relationship between natural gas consumption and real GDP during the period of 1954-1997. However, author found the unidirectional causality from natural gas consumption to economic growth. Aqeel and Butt (2001) explored causal relationships between real GDP and natural gas consumption in Pakistan for the 1955-1996 period. They revealed the absence of a cointegrated relationship between natural gas consumption and real GDP as well as the absence of a causal relationship. In cases of Australia and New Zealand, Fatai et al. (2004) failed to find a causal relationship between natural gas consumption and economic growth using Johansen-Juselius, Toda-Yamamoto, and ARDL bounds testing approaches for data from 1960 to 1999. Using annual time series data from 1965 to 2003 for Taiwan, Lee and Chang (2005) noted that natural gas consumption Granger causes economic growth. In an analysis of disaggregated energy consumption measures for Iran over the period 1967-2003, Zamani (2007) found, using VECM, long-run bidirectional causality between natural gas consumption and economic growth. Asghar, (2008) investigated the causal relationship between GDP and different types of energy consumption (gas, coal, oil, electricity) for the five South Asian Countries (Pakistan, India, Sri Lanka, Bangladesh and Nepal) by using ECM and Toda-Yamamoto approach. The author found cointegration for Pakistan and the unidirectional causal relationship from gas consumption to economic growth for Bangladesh. A study on Taiwan using shorter period of quarterly data over 
the period of 1982:1-2006:4, $\mathrm{Hu}$ and Lin, (2008) utilized the Hansen-Seo asymmetric cointegration procedure to reveal asymmetries in the relationship between natural gas consumption and economic growth for Taiwan.. Their findings using threshold VECM confirmed that, with faster adjustments of natural gas consumption than GDP, long-run equilibrium exists. In a study of the former Soviet Union within 1987-1996, Reynolds and Kolodziej (2008) concluded economic growth is cause of natural gas consumption. Sari et al. (2008) estimated ARDL model to detect cointegration even for small samples and to find unidirectional causality from industrial production and employment to natural gas consumption in case of the US monthly data from 2001:1-2005:6. Khan and Ahmad (2009) examined the demand for energy at disaggregate level (gas, electricity and coal) for Pakistan over the period 1972-2007. Their findings suggested that gas consumption responds negatively to real GDP and price changes in the short-run, however, in the long-run real GDP exerts positive effect on gas consumption. Using data of 1970-2005 and applying VECM and Johansen-Juselius method, Ighodaro (2010) found, for Nigeria, unidirectional causality running from natural gas consumption to economic growth and also found the presence of a cointegrated relationship in the long-run. Finally, Payne (2011) provided a disaggregated analysis of the causal relationship between fossil fuel consumption and real GDP in the US over the period of 1949-2006. The author noted the positive unidirectional causality from real GDP to natural gas consumption using the Toda-Yamamoto causality approach.

\section{Data and methodology}

\subsection{Data and model specification}


Following the existing studies in energy literature such as Moroney (1990), Lee (2005), Narayan and Smyth (2008), Apergis and Payne (2010) and Shahbaz et al. (2013), a multivariate model has been used to examine the nexus between real GDP and natural gas consumption through incorporating capital and trade as additional determinants of economic growth and natural gas consumption:

$$
Y_{t}=f\left(G_{t}, K_{t}, T R_{t}\right)
$$

where $\mathrm{Y}$ is the real GDP in billions of constant 2000 US dollars, G is the natural gas consumption defined by dry natural gas in billions of cubic feet, $\mathrm{K}$ is the real gross fixed capital formation in billions of constant 2000 US dollars, and TR is the total of trade defined by sum of exports and imports in billions of constant 2000 US dollars. Annual data from 1980 to 2010 were obtained from the World Bank Development Indicators (CD-ROM) and the Energy Information Administration for Tunisia's case.

Specifically, the logarithmic linear specification of Eq. (1) is as follows:

$$
y_{t}=\alpha_{0}+\alpha_{1} \cdot g_{t}+\alpha_{2} \cdot k_{t}+\alpha_{3} \cdot t r_{t}+\varepsilon_{t}
$$

where $y_{t}=\ln \left(Y_{t}\right), g_{t}=\ln \left(G_{t}\right), k_{t}=\ln \left(K_{t}\right)$, and $t r_{t}=\ln \left(T R_{t}\right) . \ln Y_{t}$ is natural $\log$ of real GDP, $\ln G_{t}$ is natural $\log$ of natural gas consumption, $\ln K_{t}$ is natural $\log$ of real capital use, $\ln T R_{t}$ is for natural $\log$ of total trade and $\varepsilon_{t}$ is residual term assumed to be normally distributed. 

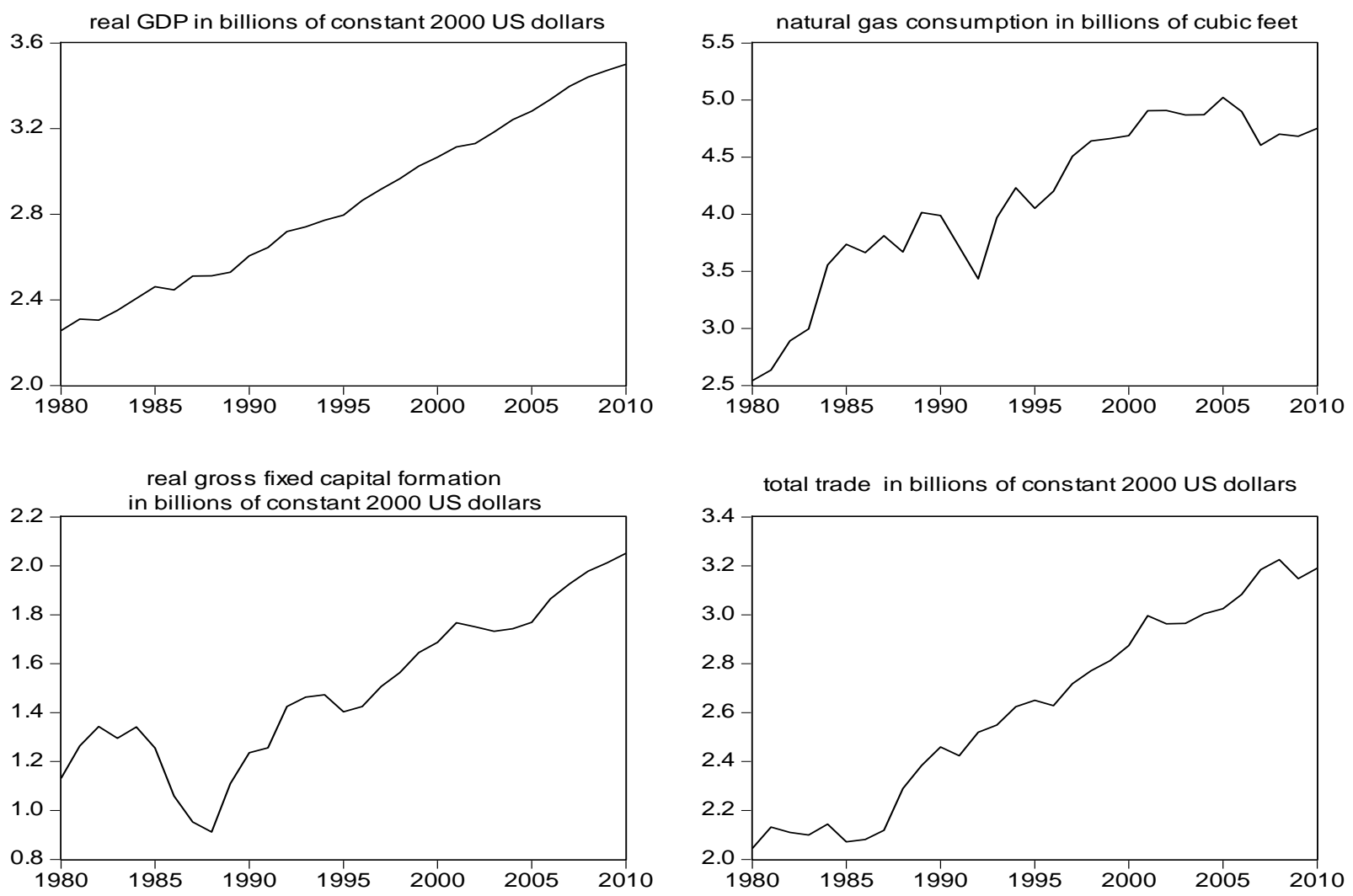

Fig 1. Plots in natural log of real GDP, natural gas consumption, real gross fixed capital formation and trade Source: compiled from World Bank and Energy Information Administration, Tunisia

\subsection{ARDL bounds testing approach}

Several econometric approaches were applied to investigate the production function, in the last three decades. With regards to univariate cointegration approaches, there are several examples including Engle and Granger (1987), Fully Modified Ordinary Least Squares (FMOLS) procedures initially suggested by Philips and Hansen (1990), and Dynamic Ordinary Least Squares (DOLS) procedures initially suggested by Saikkonen (1991) and Stock and Watson (1993). There are also many examples of multivariate cointegration procedures including Johansen (1988), Johansen and Juselius (1990), and Johansen's (1996) maximum likelihood cointegration approach. 
A recent single cointegration approach, known as Auto-Regressive Distributed Lag (ARDL) developed by Pesaran et al. (2001), has become the most widely used approach by researchers. This approach is also known as bounds testing, has certain econometric advantages compared to other traditional cointegration approaches. It solves the endogeneity problems and the inability to test hypotheses on the estimated coefficients in the long-run associated with the Engle-Granger method (Engle and Granger, 1987). It also estimates long as well as short run parameters separately in single model. The ARDL bounds testing approach is applicable whether the variables purely $\mathrm{I}(0)$, purely $\mathrm{I}(1)$, or fractionally integrated. It is found that the small sample properties of the bounds testing approach are far superior to that of multivariate cointegration (Narayan, 2005). The following unrestricted error correction regressions of Eq. (2) were estimated with real GDP in natural $\log (y)$ as the dependent variable for Tunisia:

$$
\begin{gathered}
\Delta y_{t}=\beta_{0}+\sum_{i=1}^{p} \beta_{1} \cdot \Delta y_{t-i}+\sum_{j=0}^{q} \beta_{2} \cdot \Delta g_{t-j}+\sum_{m=0}^{r} \beta_{3} \cdot \Delta k_{t-m}+\sum_{n=0}^{s} \beta_{4} \cdot \Delta t r_{t-n}+ \\
+\beta_{5} \cdot y_{t-1}+\beta_{6} \cdot g_{t-1}+\beta_{7} \cdot k_{t-1}+\beta_{8} \cdot t r_{t-1}+\mu_{t}
\end{gathered}
$$

Initially, a joint significance test, that implies no cointegration hypothesis $\left(H_{0}: \beta_{i}=0 ; \forall \mathrm{i}=5,6\right.$, $7,8)$ against the alternative hypothesis $\left(H_{1}: \beta_{i} \neq 0 ; \forall \mathrm{i}=5,6,7,8\right)$, should be performed for Eq. (3). The bounds testing approach to cointegration requires carrying out the F-test on the selected ARDL models including appropriate lag lengths of selection criterion such as Akaike Information Criterion (AIC) and Schwarz Information Criterion (SIC). The AIC criterion provides better results compared to other criterion. In this stage, we choose lag order 2. 
At the second stage, it is also possible to perform for the selected ARDL representation, a general error correction model (ECM) of Eq. (3) formulated as follows:

$$
\Delta y_{t}=\phi_{0}+\sum_{i=1}^{p} \theta_{1} \cdot \Delta y_{t-i}+\sum_{j=0}^{q} \theta_{2} \cdot \Delta g_{t-j}+\sum_{m=0}^{r} \theta_{3} \cdot \Delta k_{t-m}+\sum_{n=0}^{s} \theta_{4} \cdot \Delta t r_{t-n}+\lambda \cdot E C T_{t-1}+\xi_{t}
$$

where $\Delta$ is the first difference term; $\lambda$ is the error correction parameter, $E C T_{t-1}$ is the residuals that are obtained from the estimated cointegration model of Eq. (2), and $\xi_{t}$ is the disturbance term assumed to be uncorrelated with zero means.

The ARDL bounds test of cointegration is complemented by Johansen and Juselius's (1990) maximum likelihood to provide a sensitivity check on the results. A brief reminder of the Johansen and Juselius's (1990) multivariate cointegration methodology is illustrated below:

$$
X_{t}=A+\sum_{z=1}^{b} \Gamma_{z} \cdot X_{t-z}+\eta_{t}
$$

where $X_{t}=\left(y_{t}, g_{t}, k_{t}, t r_{t}\right)$ represents a vector of endogenous I(1) variables, $A$ is a vector of constant terms, $\Gamma$ represents coefficient matrix , $b$ denotes the lag length, and $\eta_{t}$ is the residual matrix. All variables in Eq. (5) are considered to be potentially endogenous. The cointegrating rank can be found via the trace and the maximal eigenvalue tests. The lag length of the unrestricted vector autoregressive (VAR) structure in Eq. (5) is based on minimization of Final Prediction Error (FPE), Akaike (AIC), Schwarz (SIC) and Hannan-Quinn (HQ) criteria, and the maximization of the Likelihood Ratio (LR) criterion. 


\subsection{Granger causality test}

A vector error correction model (VECM) is estimated to perform Granger-causality test (Pesaran et al., 1999). This method is followed by the two steps of Engle and Granger (1987) and employed to investigate the long-run and short-run dynamic causal relationships. The first step estimates the long-run parameters in Eq. (2) in order to obtain the residuals corresponding to the deviation from equilibrium. The second step estimates the parameters related to the short-run adjustment. The resulting equations are used in conjunction with Granger causality testing:

$$
\left(\begin{array}{c}
\Delta y_{t} \\
\Delta g_{t} \\
\Delta k_{t} \\
\Delta t r_{t}
\end{array}\right)=\left(\begin{array}{l}
\phi_{1} \\
\phi_{2} \\
\phi_{3} \\
\phi_{4}
\end{array}\right)+\sum_{c=1}^{d}\left(\begin{array}{llll}
\theta_{1,1, c} & \theta_{1,2, c} & \theta_{1,3, c} & \theta_{1,4, c} \\
\theta_{2,1, c} & \theta_{2,2, c} & \theta_{2,3, c} & \theta_{2,4, c} \\
\theta_{3,1, c} & \theta_{3,2, c} & \theta_{3,3, c} & \theta_{3,4, c} \\
\theta_{4,1, c} & \theta_{4,2, c} & \theta_{4,3, c} & \theta_{4,4, c}
\end{array}\right) \cdot\left(\begin{array}{l}
\Delta y_{t-c} \\
\Delta g_{t-c} \\
\Delta k_{t-c} \\
\Delta t r_{t-c}
\end{array}\right)+\left(\begin{array}{l}
\lambda_{1} \\
\lambda_{2} \\
\lambda_{3} \\
\lambda_{4}
\end{array}\right) \cdot E C T_{t-1}+\left(\begin{array}{l}
v_{1, t} \\
v_{2, t} \\
v_{3, t} \\
v_{4, t}
\end{array}\right)
$$

where $\phi_{j}(\mathrm{j}=1,2,3,4)$ represents the fixed country effect; $c(c=1, \ldots, d)$ is the optimal lag length determined by the Akaike information Criterion (AIC), $E C T_{t-1}$ is the estimated lagged error correction term derived from the long-run relationship presented in Eq. (2) and estimated via Eq. (6), $\lambda_{j} \quad(j=1,2,3,4)$ is the adjustment coefficient, and $v_{j, t}(j=1,2,3,4)$ is the disturbance term assumed to be uncorrelated with zero means. Opposite to Eq. (4), all error-correction vectors in Eq. (6) are estimated with the same lag structure $(p=q=r=s=d)$ that is determined in unrestricted VAR framework.

\subsection{Instability tests}


Bahmani-Oskooee and Chomsisengphet (2002) suggested that the existence of a cointegration derived from Eq. (3) does not necessarily imply that the estimated coefficients are stable. Generally, the instability of coefficients of regression equations are tested by means of Chow (1960), Brown et al. (1975), Hansen (1992), and Hansen and Johansen (1999) tests. The Chow (1960) test reveals a priori knowledge of structural breaks in the estimation period. In Hansen (1992) and Hansen and Johansen (1999) procedures, instability tests require I(1) variables and they show the long-run parameter constancy without incorporating the short-run dynamics of a model into the testing. Hence, instability tests of Brown et al. (1975), which are also known as cumulative sum (CUSUM) and cumulative sum of squares (CUSUMSQ) tests based on the recursive regression residuals, may be incorporated the short-run dynamics to the long-run through residuals. The CUSUM and CUSUMSQ statistics are updated recursively and plotted against the break points of the model. Provided that the plots of these statistics fall inside the critical bounds of $5 \%$ significance, one assumes that the coefficients of a given regression are stable. These tests are explained with more details in Farhani (2012a).

\section{Empirical results}

\subsection{Unit root tests}

The stationarity of each variable in Eq. (2) is implemented through two unit root tests: Augmented-Dickey-Fuller (ADF) of Dickey and Fuller (1979) and Phillips-Perron (PP) of Phillips and Perron (1988). The results displayed in Table-1 shows that all series in Eq. (2) appear to contain a unit root in their levels but stationary in their first differences. Hence, we conclude that all variable are integrated at order one, I(1). 
Table-1: Unit root tests

\begin{tabular}{|c|c|c|c|c|c|}
\hline Method & & $Y$ & $g$ & $K$ & $t r$ \\
\hline \multirow{2}{*}{$\begin{array}{l}\boldsymbol{A D F} \\
\text { (with intercept } \\
\text { and trend) }\end{array}$} & Level & $\begin{array}{l}-2.705 \\
(0.2419)\end{array}$ & $\begin{array}{l}-2.134 \\
(0.5073)\end{array}$ & $\begin{array}{l}-1.640 \\
(0.7523) \\
\end{array}$ & $\begin{array}{l}-2.489 \\
(0.3307)\end{array}$ \\
\hline & $\Delta$ & $\begin{array}{l}-7.004 * * * \\
(0.0000) \\
\end{array}$ & $\begin{array}{l}-5.317 * * * \\
(0.0010)\end{array}$ & $\begin{array}{l}-5.294 * * * \\
(0.0014) \\
\end{array}$ & $\begin{array}{l}-5.126^{* * * *} \\
(0.0014)\end{array}$ \\
\hline \multirow{2}{*}{$\begin{array}{l}\boldsymbol{A D F} \\
\text { (only with } \\
\text { intercept) }\end{array}$} & Level & $\begin{array}{c}0.668 \\
(0.9893) \\
\end{array}$ & $\begin{array}{l}-2.276 \\
(0.1857)\end{array}$ & $\begin{array}{l}-0.041 \\
(0.9471)\end{array}$ & $\begin{array}{l}-0.431 \\
(0.8913)\end{array}$ \\
\hline & $\Delta$ & $\begin{array}{l}-6.734 * * * \\
(0.0000) \\
\end{array}$ & $\begin{array}{l}-4.742 * * * \\
(0.0007)\end{array}$ & $\begin{array}{l}-5.342 * * * \\
(0.0002) \\
\end{array}$ & $\begin{array}{l}-5.223 * * * \\
(0.0002) \\
\end{array}$ \\
\hline \multirow{2}{*}{$\begin{array}{l}\boldsymbol{P P} \\
\text { (with intercept } \\
\text { and trend) }\end{array}$} & Level & $\begin{array}{l}-2.460 \\
(0.3439)\end{array}$ & $\begin{array}{l}-2.039 \\
(0.5571)\end{array}$ & $\begin{array}{l}-1.908 \\
(0.6254)\end{array}$ & $\begin{array}{l}-2.292 \\
(0.4252)\end{array}$ \\
\hline & $\Delta$ & $\begin{array}{l}-9.095 * * * \\
(0.0000)\end{array}$ & $\begin{array}{l}-7.763 * * * \\
(0.0000)\end{array}$ & $\begin{array}{l}-3.605 * * \\
(0.0469)\end{array}$ & $\begin{array}{l}-5.189 * * * \\
(0.0012)\end{array}$ \\
\hline \multirow{2}{*}{$\begin{array}{l}\boldsymbol{P P} \\
\text { (only with } \\
\text { intercept) }\end{array}$} & Level & $\begin{array}{c}1.581 \\
(0.9991)\end{array}$ & $\begin{array}{l}-2.276 \\
(0.1857)\end{array}$ & $\begin{array}{l}-0.041 \\
(0.9471)\end{array}$ & $\begin{array}{l}-0.336 \\
(0.9078)\end{array}$ \\
\hline & $\Delta$ & $\begin{array}{l}-6.928 * * * \\
(0.0000)\end{array}$ & $\begin{array}{l}-5.051 * * * \\
(0.0003)\end{array}$ & $\begin{array}{l}-3.556 * * \\
(0.0134)\end{array}$ & $\begin{array}{l}-5.310 * * * \\
(0.0002)\end{array}$ \\
\hline Decision & & $\mathrm{I}(1)$ & $\mathrm{I}(1)$ & $\mathrm{I}(1)$ & $\mathrm{I}(1)$ \\
\hline
\end{tabular}

$\Delta$ is the first difference term.

ADF and PP examine the null hypothesis of non-stationary.

For ADF, EViews 7 software is used to select the optimal lag length. The optimal lag length stands for the lag level that maximizes the Schwarz Information Criteria (SIC).

For PP, Barlett Kernel is used as the spectral estimation method. The bandwidth is selected using the Newey-West method.

$\mathrm{P}$-values are in parentheses and reported underneath the corresponding t-statistics.

$* * *$ and $* *$ denote the significance at $1 \%$ and $5 \%$ levels, respectively.

\subsection{ARDL cointegration method}

Given that $y_{t}, g_{t}, k_{t}$ and $t r_{t}$ share common integration properties, Eq. (3) was estimated in two stages. In the first stage of the ARDL procedure, the long-run relationship of Eq. (2) was established in two steps. Firstly, the order of lag, used to estimate later VAR or VECM models, was obtained from unrestricted VAR by minimized Final Prediction Error (FPE) criterion, Akaike Information Criterion (AIC), Schwarz Information Criterion (SIC) and Hannan-Quinn (HQ) criterion, and by maximized Likelihood Ratio (LR) criterion. The results of this stage are displayed here to conserve the optimal lag which is found to be 1 (Table 2, A). 
Table-2: A. VAR lag order selection criteria

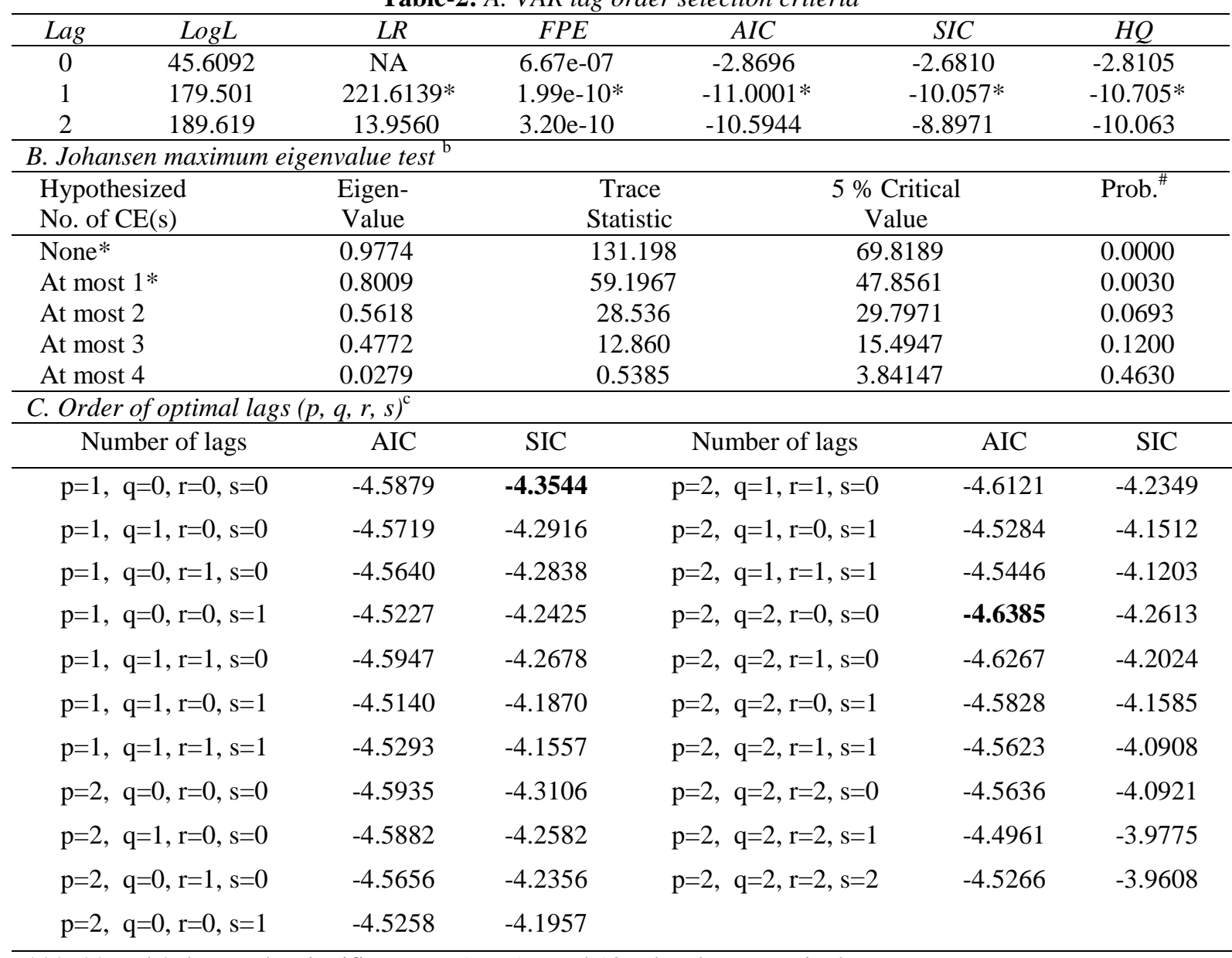

$* * *, * *$ and $*$ denote the significance at $1 \%, 5 \%$ and $10 \%$ levels, respectively.

" MacKinnon-Haug-Michelis (MHM) of MacKinnon et al. (1999) p-values.

${ }^{a}$ denotes the optimal lag selection.

${ }^{\mathrm{b}}$ Trace test indicate 1 cointegrating $\mathrm{Eq}$ at the $5 \%$ level.

${ }^{\mathrm{c}}$ Statistics in bold denote the value of the minimized AIC and SIC.

Using this lag, the result of the Johansen maximum eigenvalue test, are based on both Johansen (1988) and the modified version suggested by Reinsel and Ahn (1992). This concludes that there is one cointegrated relationship at the 5\% level of significance (Table-2.B). Secondly, the order of lags $(p, q, r, s)$ on the first differenced variables for Eq. (3) was obtained from the minimization of AIC and SIC criteria (the lag length is used to be 2). For AIC, the minimization of this criterion leads to choose the optimal lags: $\mathrm{p}=2, \mathrm{q}=2, \mathrm{r}=0, \mathrm{~s}=0$, whereas the minimization of SIC leads to choose: $\mathrm{p}=1, \mathrm{q}=0, \mathrm{r}=0, \mathrm{~s}=0$ (Table-2.C). 
The presence of a diagnostic divergence in the use of these criteria often arrives in the reality (Farhani, 2012b). In this case, it is necessary to understand very well the objective of the study, which consists to control the autocorrelation of the innovations. According to a principle of parsimony (Raykov and Marcoulides, 1999), it is advisable to estimate the model which both includes the minimum of lags and presents absence of residuals autocorrelation.

Eq. (2) was estimated to obtain the long-run and short-run coefficients for Tunisia using ARDL methodology (Table-3). The results in Table-3 indicate that natural gas consumption had a longrun and short-run positive impact on real GDP. More precisely, a $1 \%$ increase in natural gas consumption will increase real GDP by $0.028 \%$ in long-run, and $0.040 \%$ in short-run, both of which are significant at the $5 \%$ level. On the other hand, a $1 \%$ increase in real gross fixed capital formation will lead to increase real GDP by $0.342 \%$ for long-run, and $0.085 \%$ in short-run, both of which are significant at the $5 \%$ level. In the same way, a $1 \%$ increase in total trade will raise real GDP by $0.342 \%$ in long-run, and $0.085 \%$ in short-run, both of which are significant at the 1\% level. Our findings are broadly consistent with Moroney (1990), Lee (2005), Narayan and Smyth (2008), Apergis and Payne (2010), Işik (2010), Kum et al. (2012), Lim and Yoo (2012), and Shahbaz et al. (2013).

Table-3: ECM-ARDL results

\begin{tabular}{|c|c|c|c|c|c|}
\hline \multicolumn{3}{|c|}{$\begin{array}{l}\text { A. Dependent variable } \triangle y_{t} \text { based on ARDL } \\
(1,0,0,0) \text { selected lags based on SIC }\end{array}$} & \multicolumn{3}{|c|}{$\begin{array}{l}\text { B. Cointegrating vector: } \\
\text { Dependent variable } y_{t}\end{array}$} \\
\hline Regressors & Coefficients & t-ratio & Regressors & Coefficients & t-ratio \\
\hline$\Delta g_{t}$ & 0.0402 & $3.7808 * * *$ & $g_{t}$ & 0.0283 & $2.2849 * *$ \\
\hline$\Delta k_{t}$ & 0.0850 & $2.4797 * *$ & $k_{t}$ & 0.3423 & $11.028 * * *$ \\
\hline$\Delta t r_{t}$ & 0.1204 & $3.0479 * * *$ & $t r_{t}$ & 0.5027 & $7.0072 * * *$ \\
\hline Constant & 0.4126 & $2.0949 * *$ & Constant & 3.5381 & $-13.322 * * *$ \\
\hline \multicolumn{3}{|c|}{$\mathrm{R}^{2}=0.997, \mathrm{~F}=204.972 * * *, \mathrm{DW}=2.055$} & $E C T_{t-1}$ & -0.5434 & $-2.3532 * *$ \\
\hline
\end{tabular}


The error correction term $\mathrm{ECT}_{\mathrm{t}-1}$ represents the speed of adjustment of $\Delta y_{t}$ to its long-run equilibrium following a shock. The coefficient of -0.5434 is significant at $5 \%$ level with a negative sign expected, suggesting that a deviation from long-run equilibrium level of real GDP in 1 year is corrected by $54.34 \%$ in every year. Moreover, a significant error correction confirms the existence of a stable long-run relationship between the regressors $\left(g_{t}, k_{t}\right.$ and $\left.t r_{t}\right)$ and the dependent variable $\left(y_{t}\right)$.

The diagnostic tests indicate that the model passed most of the tests for serial correlation, functional form, normality and heteroscedasticity. The high value of $\mathrm{R}^{2}$ for ECM-ARDL model shows that the adjustment of ARDL model is extremely good $\left(\mathrm{R}^{2}=0.997 \rightarrow 1\right)$. The F-statistic which measure the joint significance of all regressors in the models are statistically significant at 5\% level, and the Durbin-Watson statistic for the model is approximately equal two (absence of errors autocorrelation).

\subsection{Granger causality results}

According to the Johansen maximum eigen-value test results revealed in Table-2.B, there exists one cointegrating relationship between $y_{t}, g_{t}, k_{t}$ and $t r_{t}$. Therefore, the Granger causality test was conducted to Eq. (6) as such that only four long-run relationships were estimated with an error correction term (Table-2.B). Table-4 summarizes the results of long-run and short-run Granger causality. According to the coefficient on the lagged error-correction term, there exists a long-run relationship among the variables in the form of Eq. (2) as the error-correction term is statistically significant, which also confirms the results of the bounds test. In term of long-run and short-run Granger causality, there is long-run Granger causality running from natural gas consumption, real gross fixed capital formation and trade to real GDP at the 5\% level and short- 
run Granger causality running from natural gas consumption, real gross fixed capital formation and trade to real GDP at 5\%, 5\% and 10\% level, respectively. There is also long-run Granger causality running from real GDP, real gross fixed capital formation and trade to natural gas consumption at $1 \%$ level, however, short-run Granger causality running only from real GDP to natural gas consumption. In case of real gross fixed capital formation as dependent variable, there is long-run Granger causality running from real GDP, natural gas consumption, and trade to real gross fixed capital formation at $10 \%$ level and short-run Granger causality running only from real GDP and natural gas consumption to real gross fixed capital formation at $1 \%$ and $10 \%$ level, respectively. Finally, there is long-run Granger causality running from real GDP, natural gas consumption and real gross fixed capital formation to trade at $1 \%$ level, however, there is no short-run Granger causality.

Table-4: Granger causality test

\begin{tabular}{|c|c|c|c|c|c|}
\hline \multirow[t]{2}{*}{$\begin{array}{l}\text { Dependent } \\
\text { Variable }\end{array}$} & \multicolumn{4}{|c|}{$\begin{array}{c}F \text {-statistics } \\
\text { (Probabilities) }\end{array}$} & \multirow[t]{2}{*}{$\begin{array}{l}E C T_{t-1} \\
\text { [t-stat] }\end{array}$} \\
\hline & $\Delta y_{t}$ & $\Delta g_{t}$ & $\Delta k_{t}$ & $\Delta t r_{t}$ & \\
\hline$\Delta y_{t}$ & \# & $\begin{array}{l}4.874 * * \\
(0.0203)\end{array}$ & $\begin{array}{l}3.812 * * \\
(0.0400)\end{array}$ & $\begin{array}{c}3.481^{*} \\
(0.0507)\end{array}$ & $\begin{array}{l}-0.543 * * \\
{[-2.3532]}\end{array}$ \\
\hline$\Delta g_{t}$ & $\begin{array}{l}3.749 * * \\
(0.0416)\end{array}$ & \# & $\begin{array}{l}2.49257 \\
(0.1121)\end{array}$ & $\begin{array}{c}0.493 \\
(0.8168)\end{array}$ & $\begin{array}{l}-0.203 * * * \\
{[-2.9215]}\end{array}$ \\
\hline$\Delta k_{t}$ & $\begin{array}{c}10.788 * * * \\
(0.0016)\end{array}$ & $\begin{array}{c}3.074 * \\
(0.0691)\end{array}$ & \# & $\begin{array}{c}1.638 \\
(0.2518)\end{array}$ & $\begin{array}{l}-0.123^{*} \\
{[-1.7388]}\end{array}$ \\
\hline$\Delta t r_{t}$ & $\begin{array}{c}2.315 \\
(0.1313)\end{array}$ & $\begin{array}{c}0.655 \\
(0.7048)\end{array}$ & $\begin{array}{l}2.19661 \\
(0.1463)\end{array}$ & \# & $\begin{array}{l}-0.055 * * * \\
{[-2.7528]}\end{array}$ \\
\hline
\end{tabular}

\subsection{Instability tests results}

The AIC based error-correction model of Eq. (3) is selected to implement the CUSUM and CUSUMSQ stability tests. The related graphs of these tests are presented in Fig 2. As can be seen from the graphs of Fig 2, the plots of CUSUM and CUSUMSQ statistics are well within the 
critical bounds at 5\% significance level, implying that all coefficients in the error-correction model are stable. Therefore, the selected output model can be used for policy decision making purposes, such that the impact of policy changes considering the explanatory variables of output equation will not cause major distortion in the level of real GDP, since the parameters in this equation seem to follow a stable pattern during the estimation period (Shahbaz et al. 2013).
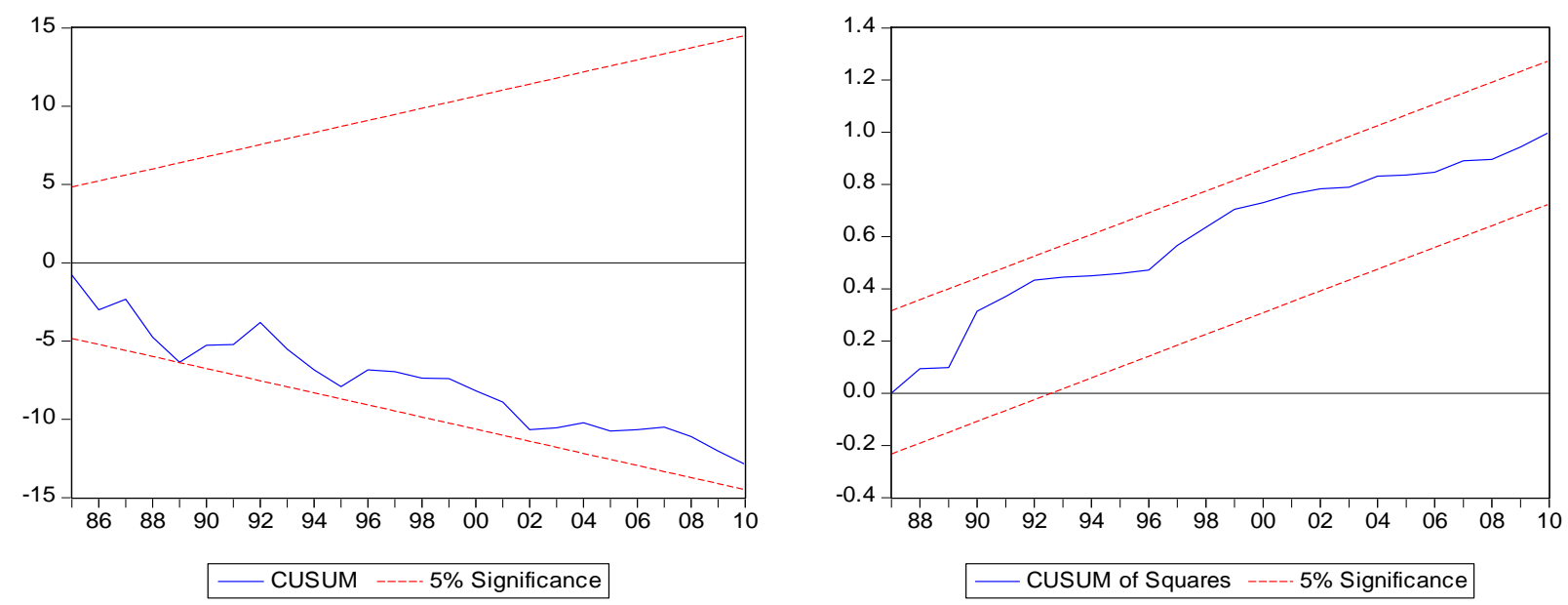

Fig 2. Plots of CUSUM and CUSUMSQ of recursive residuals

\section{Conclusion and policy implications}

This paper aims to analyze the dynamic relationships between real GDP, natural gas consumption, real gross fixed capital formation and trade in Tunisia over the period 1980-2010. The long-term relationship, in which real GDP is as a dependent variable, is used to test the short-term and long-term elasticities of real GDP with respect to explanatory variables. Our results validated the presence of cointegration between the variables. Furthermore, natural gas consumption increases economic growth. Real capital use stimulates economic growth. Trade boosts domestic output. We find a feedback effect between natural gas consumption and economic growth. The relationship between natural gas consumption and trade is bidirectional and the same inference is drawn for trade and economic growth. Bidirectional causality is found 
between capital use and natural gas consumption and the same is true for capital use and economic growth (trade). In short term, the relationship between natural gas consumption and economic growth is bidirectional and the same is true for capital use and domestic output.

The feedback effect between natural gas consumption and domestic output suggests that energy exploring (natural gas) policies should be adopted to sustain long term economic growth. The adoption of energy conservation polices will not only limit domestic output but also reduce demand for natural gas in return. The decline in domestic output also lowers Tunisia's export potential and hence trade. This implies that the government must give its attention to increasing research and development expenditures for exploring other renewable sources of energy to meet rising energy demands. Renewable energy is an appropriate source to stimulate economic and trade activity in Tunisia. Technologies that promote sustainable energy including renewable energy sources such as hydroelectricity, solar energy, wind energy, wave power, geothermal energy and tidal power must be adopted by the Tunisian government.

\section{References}

Apergis, N., Payne, J.E., 2010. Natural gas consumption and economic growth: a panel investigation of 67 countries. Applied Energy, 87, 2759-2763.

Aqeel, A., Butt, M.S., 2001. The relationship between energy consumption and economic growth in Pakistan. AsiaPacific Development Journal, 8, 101-110.

Asghar, Z., 2008. Energy-GDP relationship: a causal analysis for the five countries of South Asia. Applied Econometrics and International Development, 8, 167-180.

Bahmani-Oskooee, M., Chomsisengphet, S., 2002. Stability of M2 money demand function in industrial countries. Applied Economics, 34, 2075-2083.

Brown, R.L., Durbin, J., Evans, J.M., 1975. Techniques for testing the constancy of regression relationships over time. Journal of the Royal Statistical Society, 37, 149-192.

Chow, G.C., 1960. Tests of equality between sets of coefficients in two linear regressions. Econometrica, 28, 591605.

Dickey, D.A., Fuller, W.A., 1979. Distribution of the estimators for autoregressive time series with a unit root. Journal of the American Statistical Association, 74, 427-431.

Engle, R.F., Granger C.W.J., 1987. Co-integration and error correction: Representation, estimation, and testing. Econometrica, 55, 251-276.

Farhani, S., 2012a. Tests of parameters instability: Theoretical study and empirical analysis on two types of models (ARMA model and market model). International Journal of Economics and Financial Issues, 2, 246-266. 
Farhani, S., 2012b. Impact of oil price increases on U.S. economic growth: Causality analysis and study of the weakening effects in relationship. International Journal of Energy Economics and Policy, 2, 108-122.

Fatai, K., Oxley, L., Scrimgeour, F.G., 2004. Modelling the causal relationship between energy consumption and GDP in New Zealand, Australia, India, Indonesia, the Philippines, and Thailand. Mathematics and Computers in Simulation, 64, 431-445.

Hansen, B.E.,1992. Tests for parameter instability in regressions with I(1) processes. Journal of Business and Economic Statistics, 10, 321-335.

Hansen, H., Johansen, S., 1999. Some tests for parameter constancy in cointegrated VAR-models. Econometrics Journal, 2, 306-333.

Hu, J.L., Lin, C.H., 2008. Disaggregated energy consumption and GDP in Taiwan: A threshold co-integration analysis. Energy Economics, 30, 2342-2358.

Ighodaro, C.A.U., 2010. Co-integration and causality relationship between energy consumption and economic growth: Further empirical evidence for Nigeria, Journal of Business Economics and Management, 11, 97-111.

Işik, C., 2010. Natural gas consumption and economic growth in Turkey: a bound test approach. Energy Systems, 1, 441-456.

Johansen, S., 1988. Statistical analysis of cointegrating vectors. Journal of Economic Dynamics and Control, 12, 231-254.

Johansen, S., 1996. Likelihood-Based Inference in Cointegrated Vector Autoregressive Models. Oxford University Press, Oxford.

Johansen, S., Juselius, K., 1990. Maximum likelihood estimation and inference on cointegration--with application to the demand for money. Oxford Bulletin of Economics and Statistics, 52,169-210.

Khan, M.A., Ahmad, U., 2009. Energy demand in Pakistan: A disaggregate analysis. The Pakistan Development Review, 47, 437-455.

Kum, H., Ocal, O., Aslan, A., 2012. The relationship among natural gas energy consumption, capital and economic growth: Bootstrap-corrected causality tests from G-7 countries. Renewable and Sustainable Energy Reviews, 16, 2361-2365.

Lee, C.C., 2005. Energy consumption and GDP in developing countries: a cointegrated panel analysis. Energy Economics, 27, 415-427.

Lee, C.C., Chang, C.P., 2005. Structural breaks, energy consumption, and economic growth revisited: Evidence from Taiwan. Energy Economics, 27, 857-872.

Lim, H.J., Yoo, S.H., 2012. Natural gas consumption and economic growth in Korea: A causality analysis. Energy Sources, Part B: Economics, Planning, and Policy, 7, 169-176.

Lütkepohl, H., 1982. Non-causality due to omitted variables. Journal of Econometrics, 19, 367-378.

MacKinnon, J.G., Haug, A.A., Michelis, L., 1999. Numerical distribution functions of likelihood ratio tests for cointegration. Journal of Applied Econometrics, 14, 563-577.

Moroney, J.R., 1990. Energy consumption, capital and real output: A comparison of market and planned economies. Journal of Comparative Economics, 14, 199-220.

Narayan, P.K., 2005. The saving and investment nexus for China: evidence from cointegration tests. Applied Economics, 37, 1979-1990.

Narayan, P.K., Smyth, R., 2008. Energy consumption and real GDP in G7 countries: new evidence from panel cointegtration with structural breaks. Energy Economics, 30, 2331-2341.

Payne, J.E., 2011. US disaggregate fossil fuel consumption and real GDP: An empirical note. Energy Sources, Part B: Economics, Planning, and Policy, 6, 63-68.

Pesaran, H.M., Shin, Y., Smith, R.P., 1999. Pooled mean group estimation of dynamic heterogeneous panels. Journal of the American Statistical Association, 94, 621-634.

Pesaran, M.H., Shin, Y., Smith, R.J., 2001. Bounds testing approaches to the analysis of level relationships. Journal of Applied Econometrics, 16, 289-326.

Phillips, P.C.B., Hansen, B.E., 1990. Statistical inference in instrumental variables regression with I(1) processes. Review of Economic Studies, 57, 99-125.

Phillips, P.C.B., Perron, P., 1988. Testing for a unit root in time series regression. Biometrika, 75, 335-346.

Raykov, T., Marcoulides, G.A., 1999. On desirability of parsimony in structural equation model selection. Structural Equation Modeling, 6, 292-300.

Reinsel, G.C., Ahn, S.K., 1992. Vector autoregressive models with unit roots and reduced rank structure: estimation, likelihood ratio test, and forecasting. Journal of Time Series Analysis, 13, 353-375.

Reynolds, D.B., Kolodziej, M., 2008. Former Soviet Union oil production and GDP decline: Granger causality and the multi-cycle Hubbert curve. Energy Economics, 30,271-289. 
Saikkonen, P., 1991. Asymptotically efficient estimation of cointegration regressions. Econometric Theory, 7, 1-21.

Sari, R., Ewing, B.T., Soytas, U., 2008. The relationship between disaggregate energy consumption and industrial production in the United States: An ARDL approach. Energy Economics, 30, 2302-2313.

Shahbaz, M., Lean, H.H., Farooq, A., 2013. Natural gas consumption and economic growth in Pakistan. Renewable and Sustainable Energy Reviews, 18, 87-94.

Stock, J.H., Watson, M.W., 1993. A simple estimator of cointegrating vectors in higher order integrated systems. Econometrica, 61, 783-820.

Yang, H.Y., 2000. A note on the causal relationship between energy and GDP in Taiwan. Energy Economics, 22, 309-317.

Yu, E.S.H., Choi, J.Y., 1985. The causal relationship between energy and GNP: An international comparison. Journal of Energy and Development, 10, 249-272.

Zamani, M., 2007. Energy consumption and economic activities in Iran. Energy Economics, 29, 1135-1140. 